\title{
INVESTIGATIONS OF GLACIER HYDROLOGICAL SYSTEMS USING DYE TRACER TECHNIQUES: OBSERVATIONS AT PASTERZENGLETSCHER, AUSTRIA
}

\author{
By MARION BURKIMSHER \\ (School of Geography, University of Manchester, Manchester M13 9PL, England)
}

\begin{abstract}
A comprehensive series of dye tracer tests was undertaken over two summers at Pasterzengletscher, Austria, and from these a number of important conclusions can be drawn. A lateral division of drainage on the lower tongue was proved, but this was not determined by the direction of oblique crevasses. Water from many moulins passed into two or more drainage courses, as shown by repeated patterns of multiple peaks on the time/concentration curves. The spatial pattern of travel times from different moulins on the tongue was complex, although it remained stable over time. Repeated tracer tests showed that throughflow velocities varied by up to an order of magnitude during a single day. Maximum velocities occurred at the time of peak discharge, and probably the large diurnal velocity variations are caused by changes in the proportion of the length which has channel-full pressure flow. However, seasonal velocity variations were much smaller, although changes in outflow discharge were larger than in the diurnal case. This gives strong support to the concept that channels adjust in size to the average water discharge passing through, and that these changes occur over a matter of days or a few weeks.
\end{abstract}

RÉSUMÉ. Recherches sur les réseaux hydrologiques dans un glacier par traçeurs colorés: Observations sur le Pasterzengletscher, Autriche. On a entrepris pendant deux ètés sur le Pasterzengletscher en Autriche une série complète d'essais avec des traçeurs colorés, et on peut en tirer plusieurs conclusions importantes. On a mis en évidence une division latérale de l'émissaire dans le bas de la langue mais cette division n'est pas déterminée par la direction des crevasses obliques. L'eau venant de beaucoup de moulins passe par deux ou plus cheminements différents comme le montre la répétition de phénomène de pointes multiples dans les courbes de concentrations de colorants avec le temps. La distribution dans l'espace de délais de réapparition pour différents moulins sur la langue est complexe bien qu'elle reste constante dans le temps. La répétition d'essais de traceurs a montré que les vitesses d'écoulement varient de plus d'un ordre de grandeur au cours d'une seule journée. Les vitesses les plus fortes se produisent au moment des pointes de débit, et les plus fortes variations journalières de vitesses résultant des changements dans la proportion de la longueur du parcours oủ l'écoulement est en charge. Cependant les variations saisonnières de vitesse sont beaucoup plus faibles, bien que les changements dans les débits soient beaucoup plus forts que dans le cas des variations journalières. Ceci étaye fortement l'hypothèse que les cheneux adaptent leur section au débit liquide moyen qui les traverse et que cette adaptation se réalise en quelques jours ou en peu de semaines.

ZuSAMmENFASSUNG. Untersuchungen an hydrologischen Systemen in Gletschern mit Farbspurmethoden: Beobachtungen an der Pasterzengletscher, Österreich. Auf der Pasterzengletscher in Osterreich wurde während zweier Sommer eine umfangreiche Reihe von Farbspurversuchen unternommen, die zu einigen wichtigen Schlussfolgerungen führen. An der unteren Zunge liess sich eine seitliche Aufteilung des Abflusses nachweisen, die jedoch nicht durch die Richtung schräger Spalten bestimmt wurde. Wasser aus vielen Gletschermühlen floss in zwei oder mehr Abflussbahnen, was sich aus dem wiederholten Auftreten von mehrfachen Maxima in den Kurven der zeitlichen Konzentration ergab. Die räumliche Verteilung der Laufzeiten aus verschiedenen Mühlen auf der Zunge war kompliziert, blieb aber zeitlich stabil. Wiederholte Spurenversuche zeigten, dass die Durchflussgeschwindigkeiten während eines Tages bis zu einer Grössenordnung schwankten. Die höchsten Geschwindigkeiten traten zur Zeit des stärksten Abflusses auf; die grossen täglichen Schwankungen werden vermutlich durch Änderungen des Anteils des Flusses unter Druck in vollgefüllten Kanälen an der Abflusslänge verursacht. Jedoch waren die jahreszeitlichen Geschwindigkeitsschwankungen weit geringer, obwohl die Änderungen im Abfluss grösser waren als beim Tagesgang. Das Konzept, dass Wasserführungen ihre Grösse dem mittleren Wasserabfluss anpassen und solche Änderungen in einigen Tagen oder Wochen vor sich gehen, erfährt dadurch eine starke Stütze. 


\section{INTRODUCTION}

The use of dye tracer techniques for indirect examination of the internal hydrology of glaciers has become common in recent years. For the research programme described here, such techniques were exploited to the full and, because a very comprehensive set of data was collected (Burkimsher, unpublished), a number of important conclusions can be drawn about the spatial and temporal variations of internal drainage channels.

One of the earliest series of tracer tests carried out on glaciers was on Storglaciären and Mikkaglaciären, Sweden, where Stenborg (1969) used a conductivity meter to detect salt tracer. From the results of tests involving several moulins, Stenborg deduced that there was a lateral division of the internal drainage network at both glaciers. He suggested that this division of melt water towards the glacier margins was caused by oblique crevasses. Such a pattern also was noted on Austre Okstindbreen, Norway (Theakstone and Knudsen, 1981).

Flow velocities (calculated from measured travel times and straight-line distances) of most of the reported tracer results have been between 0.2 and $1.5 \mathrm{~m} \mathrm{~s}^{-1}$ (Stenborg, 1969; Krimmel and others, 1973; Behrens and others, 1975; Theakstone and Knudsen, 1981; Collins, 1982). Travel times from moulins on the glacier tongue to the snout normally have been in the range of a few minutes to a few hours. This suggests that little storage of water, or delay in its passage through the system, occurs, at least in the ablation area, and that the daily peak of discharge from a glacier is caused directly by the through passage of a peak in input. Some tracer experiments, however, have exhibited much lower throughflow velocities. Delay as water passes through snow in the accumulation area can cause transit times to the snout to be in the range of days to months (Lang and others, [1981]; Ambach and Eisner, [1981]). However, in some instances, extremely low velocities from input points in the ablation area have also been recorded. Dye injected into a moulin on South Cascade Glacier eventually issued from a spring in the ice $100 \mathrm{~m}$ away, and the estimated mean velocity was $0.02 \mathrm{~m} \mathrm{~s}^{-1}$ (Krimmel and others, 1973). A later experiment on the same glacier also showed long passage times when dye was injected directly into the subglacial water system and from another point on the surface (Krimmel, 1978). Very slow seepage of dye from one crevasse to another was observed on Austre Okstindbreen (Theakstone and Knudsen, 1981), and repeated negative results, when no dye was observed to emerge from the snout over a long period, were obtained from some moulins on this glacier, although throughflow velocities from other moulins were very rapid. This variety of results suggests that internal drainage systems may be more complex than is sometimes supposed.

Repeated tests from some moulins have indicated that throughflow velocities are highest at times of peak daily discharge (Behrens and others, 1975; Theakstone and Knudsen, 1981; Collins, 1982). Large variations from one year to the next have been observed on Austre Okstindbreen (Theakstone and Knudsen, 1981) and, together with the changing position of the main outflow stream, these indicate that major configuration changes of glacier hydrological systems can occur.

The diversity of results and conclusions drawn from earlier tracer experiments provided the incentive for a more comprehensive series of dye tracer tests to be carried out over a substantial time period at Pasterzengletscher, Austria.

\section{PHYSICAL SETTING}

Pasterzengletscher has a $4.5 \mathrm{~km}$ valley tongue with an average surface slope of $5^{\circ}$, separated from the gentle slopes of the accumulation area by a steep, horseshoe-shaped ice fall (Fig. 1). 


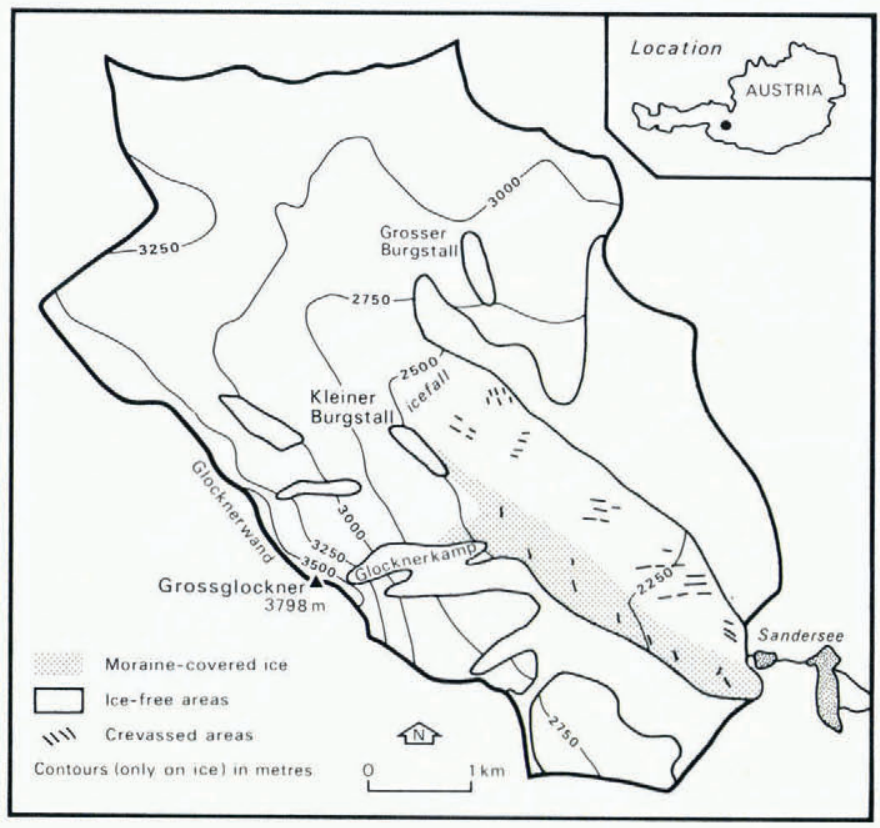

Fig. 1. Map of Pasterzengletscher catchment.

$62 \%$ of the total catchment area of $27 \mathrm{~km}^{2}$ is permanently ice-covered. The annual equilibrium line lies at a height of about $2800 \mathrm{~m}$ a.s.l. From the slopes of Glocknerwand a secondary ice stream joins the main tongue from the south. A significant supraglacial moraine cover, which originates from the cliffs of Kleiner Burgstall and Glocknerkamp, covers the southern third of the surface of the lower part of the tongue. The moraine-covered part also defines the area of the glacier surface with right-trending crevasses; the part not covered with moraine has left-trending crevasses.

\section{EXPERIMENTAL DESIGN}

During the summers of 1979 and 198057 tracer tests from a total of fifteen input points (Fig. 2) were carried out on Pasterzengletscher. In 1979, eight input points were tested between 14 August and 6 September, with one test from each. In 1980, four of the points were positively re-identified, and moulins very close to the original points were used for the other four. Most of the sites were on the lower tongue; the largest streams were selected for major study, as they influence most strongly the outflow characteristics. In 1980, most observations were carried out during three separate periods — early summer (period 1:24 June-2 July), high summer (period 2: 19 July-8 August), and late summer (period 3: 6-19 September). The tests from points A, B, and $\mathrm{C}$ on the upper tongue were carried out by Dr P Ramspacher (unpublished) at the end of August 1980. Altogether, ten input points were tested in more than one period, although poor weather in the first period permitted only three tests to be done then. In addition, three major moulins were selected for repeated daily testing. 


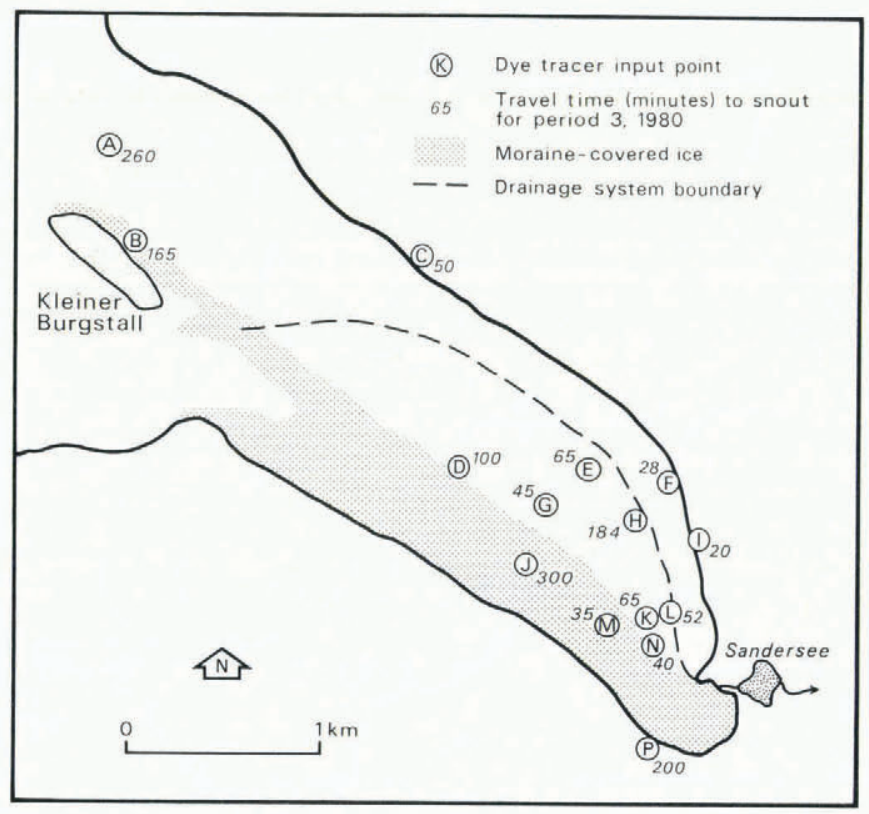

Fig. 2. Map of dye tracer input points on glacier tongue.

For three, tests in 1979 fluorescein was used as the tracer and was detected visually. Rhodamine B powder was used for the other 1979 tests and for a few in 1980. Rhodamine WT was used for all other tests; as it is supplied in liquid form, it is much superior to the other dyes for use in the field. A Turner Designs field fluorometer, calibrated to standard concentrations before and after each field season, was used to record the passage of the dye cloud. Because of the absence of natural fluorescent material in the glacial melt water, positive identification of concentrations down to 0.01 parts per billion could be achieved.

Some problems were experienced in recording the passage of dye from the glacier snout. In 1979, discrete samples were taken frequently from the main outflow stream. In 1980, continuous recording equipment was available, but two outlet streams were revealed from the glacier. Initially, these joined together a short way under the snout, before emerging as one, but later in the summer the confluence was revealed as the glacier margin retreated. As the water from the two streams was not fully mixed before it joined the Sandersee, continuous recording had to be carried out at one stream and discrete samples taken at regular intervals from the other. All these samples were analysed within a few days, and were corrected to a standard temperature by the formula given by Turner Designs (1976).

\section{SUMMARY OF RESULTS}

Information about the internal hydrological system can be gained from the dye tracer experiments in a number of ways: in which of the outflow streams the dye appeared, the shape of the time/concentration curves, and the variation of delays between dye input and outflow from moulin to moulin and over time periods of different duration. 


\section{Lateral division of the system}

Table I indicates which input points fed which outflow stream, and an approximate position of the "watershed" between the two systems is shown on Figure 2. The drainage division is not clear cut for two reasons: some moulins fed water into both outflow streams, and the major routeway from one moulin $(\mathrm{N})$ changed during the 1980 summer.

At least six of the fifteen tested input points fed both outflow streams, and more may have done so: sampling was not always comprehensive at the secondary outflow stream. The time/concentration curves for the moulin $\mathrm{N}$ tests showing the change in outflow stream, are given in Figure 3. On 30 June, water from this moulin passed into the left stream system. However, from the early morning test on 24 July, most dye emerged in the right outflow stream although, later the same day, the main outflow was again from the left stream, a smaller amount continuing to emerge from the right one. Subsequent tests ( 8 and 11 September) indicated that the right stream had captured most of the flow but, during peak mid-afternoon discharge, some water continued to pass into the left system.

One interesting anomaly was that most moulins on the lower tongue fed the right stream although its discharge was only about half that of the left stream. The "watershed" was far from central and most of the water entering many moulins on left-trending crevasses reappeared in the right outflow stream. However, water entering the centrally placed moulins on the upper tongue (A and B) appeared in the larger, left outflow stream, which must gain most of its discharge from the upper areas of the glacier.

\section{Multiple peaks of concentration}

In addition to many test results exhibiting two peaks of concentration, in that tracer emerged from separate outflow streams, multiple peaks of concentration were commonly recorded at the same outflow stream. Over short periods, these often showed repeatable patterns, such as those recorded from the moulin M tests on 30 July 1980 (Fig. 4). Of the 15 input points tested, nine

TABLE I. LATERAL DIVISION OF DRAINAGE

$\begin{array}{cccc}\text { Moulin } & \text { Year } & \text { Left stream } & \text { Right stream } \\ \text { A } & 1980 & * & \\ \text { B } & 1980 & * & * \\ \text { C } & 1980 & * & * \\ \text { D } & 1980 & & \\ \text { E } & 1980 & 0 & * \\ \text { F } & 1980 & * & 0 \\ \text { G } & 1980 & 0 & * \\ \text { H } & 1980 & 0 & * \\ \text { I } & 1979 / 80 & * & * \\ \text { J } & 1980 & & * \\ \text { K } & 1980 & 0 & 0 \\ \text { L } & 1980 & 0 & * \\ \text { M } & 1980 & & * \\ \text { N } & \text { early } 1980 \text { tests } & * & \\ \text { N } & \text { later } 1980 \text { tests } & 0 & \\ \text { P } & 1980 & & \\ \text { * most dye outflow. } & & \end{array}$




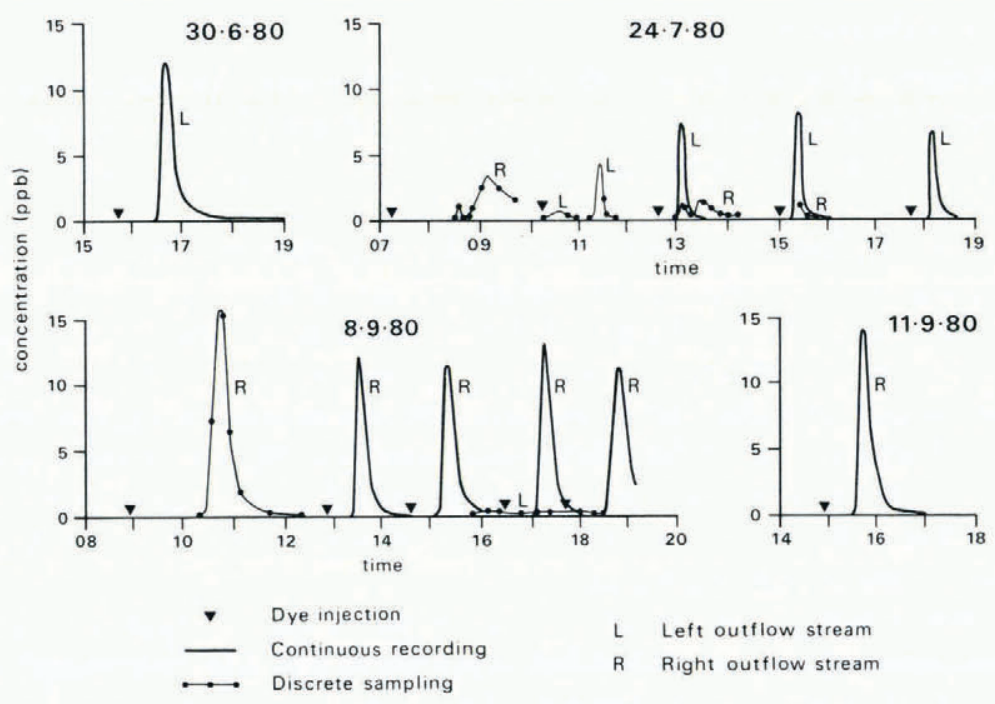

Fig. 3. Time/concentration curves from moulin $N$ tracer tests.

exhibited multiple peaks once or more. Two sets of moulins never had multiple peaks: C, F, and I (three points showing very high throughflow velocities and all lying close to the left margin), and $\mathrm{A}, \mathrm{J}$, and P (from which throughflow times were so long that the complete curve may not have been recorded).

Repeated tests from the same moulins showed that the probability of occurrence of multiple peaks varied markedly during the day and over the summer: multiple peaking was most likely when dye was injected between $13.00 \mathrm{~h}$ and $19.00 \mathrm{~h}$ (Table II), and probably especially in the first half of that period. This correlates closely with the time of highest daily discharge through the system. This pattern of association of high discharge and greater probability of multiple peaks also appeared in the seasonal results (Table III). In period 2, when discharge was at the summer maximum, multiple peaks were almost twice as probable as in period 3 , when discharge was much lower.

\section{Spatial pattern of throughflow velocities}

Problems in assessing throughflow velocities between moulins and the glacier snout include the fact that the true distance travelled is unknown; only an approximation can be made using the straight-line distance. As transit from the same moulin varied markedly during a single day

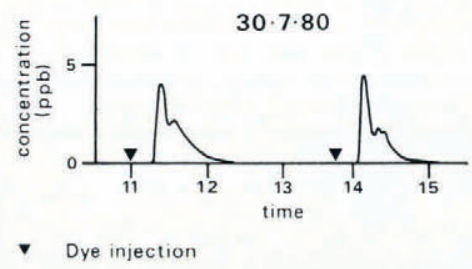

Fig. 4. Time/concentration curves from moulin $M$. 
TABLE II. DAILY DISTRIBUTION OF MULTIPLE PEAKS

\begin{tabular}{|c|c|c|c|c|c|c|c|c|}
\hline \multirow[t]{2}{*}{ Moulin } & \multicolumn{4}{|c|}{1980 period 2} & \multicolumn{4}{|c|}{1980 period 3} \\
\hline & $7-10 \mathrm{~h}$ & $10-13 \mathrm{~h}$ & $13-16 \mathrm{~h}$ & $16-19 \mathrm{~h}$ & $7-10 \mathrm{~h}$ & $10-13 \mathrm{~h}$ & $13-16 \mathrm{~h}$ & $16-19 \mathrm{~h}$ \\
\hline $\mathrm{E}$ & No & No & Yes & Yes & Yes & No & Yes & Yes \\
\hline G & No & . & Yes & . & No & No & . & . \\
\hline M & . & Yes & Yes & . & . & No & . & . \\
\hline $\mathrm{N}$ & Yes & Yes & Yes & $?$ & No & No & Yes & Yes \\
\hline
\end{tabular}

Yes: Some tests from this point showed multiple peaking.

No: No tests from this point showed multiple peaking.

: No tests done from this point during this period.

and, to some extent, on a seasonal basis, all calculated velocities were corrected to maximum velocity (occurring at the time of peak discharge), using the patterns described below (Fig. 6), and velocities were compared only with others relating to the same observation periods.

The travel times (Fig. 2), calculated as the time from injection at the input point to the time of peak concentration at the outflow stream, were all measured during the late summer season in 1980. The wide spread of values, even over small areas of the glacier, indicates that the internal drainage system of the Pasterzengletscher is more complex than might be expected. To attempt to find some order in the complex spatial pattern, the input points were listed from "fastest" to "slowest" for each period (Table IV), excluding period 1 1980, when insufficient tests were completed, and Spearman's rank correlation coefficient was calculated. The analysis confirmed that there was a significant relationship between the 1979 and 1980 period 2 data, and between the 1980 period 2 and period 3 data. Thus, although the cause of the irregular spatial pattern is obscure, the pattern is stable over time.

Input points were also grouped into "fast", "intermediate" and "slow" classes, with boundaries at $(\bar{x}+1 s)$ and $(\bar{x}-0.5 s)$. The grouping (Table IV) revealed that the two streams (C and I) which enter the system at the left margin, together with moulin $\mathrm{F}$, which also is very close to the margin, are associated with a fast-flowing trunk stream. The absence of multiple peaks on the time/concentration curves from these points, and the fact that they all feed the left outflow stream, also indicate that they are connected to a different drainage network from most of the other points.

TABLE III. OCCURRENCE OF MULTIPLE PEAKS IN EACH PERIOD

$\begin{array}{ccccc}\text { Moulin } & 1979 & \text { period 1 } 1980 & \text { period 2 } 1980 & \text { period } 31980 \\ \text { D } & \text { Yes } & . & \text { Yes } & \text { No } \\ \text { E } & . & . & \text { Yes } & \text { Yes } \\ \text { G } & \text { Yes } & \text { Yes } & \text { Yes } & \text { No } \\ \text { H } & . & . & ? & \text { Yes } \\ \text { K } & . & . & \text { Yes } & \text { No } \\ \text { L } & . & . & \text { Yes } & \text { Yes } \\ \text { M } & . & . & \text { Yes } & \text { No } \\ \text { N } & \text { No } & \text { No } & \text { Yes } & \text { Yes }\end{array}$

(Moulin B was tested only once, between periods 2 and 3, 1980, and it showed a multiple peak).

Yes: Some tests from this point showed multiple peaking.

No: No tests from this point showed multiple peaking.

: No tests done from this point during this period. 


\section{TABle IV. Spatial Variation of velocities}

All velocities in $\mathrm{m} \mathrm{s}^{-1}$ and corrected to time of maximum daily velocity.

1979

$\begin{array}{llll}\text { I } & 0.80 & \text { I } & 1.83 \\ & & & \\ & & & \\ \text { E } & 0.60 & \text { D } & 0.75 \\ \text { G } & 0.58 & \text { E } & 0.58 \\ \text { F } & 0.43 & \text { G } & 0.58 \\ \text { N } & 0.42 & \text { M } & 0.52 \\ & & \text { N } & 0.44\end{array}$

$\begin{array}{ll}\text { H } & 0.29\end{array}$

K $\quad 0.23$

D $<0.13$

$$
\text { Mean } \bar{x}=0.43
$$

Standard error $s=0.22$

$\bar{x}-0.5 s=0.32$

$\bar{x}+1 s=0.65$ period 21980

1.83

K $\quad 0.18$

L $\quad 0.11$

J $<0.06$

$\mathrm{H}<0.06$

period 31980

C 1.07

I 0.92

F 0.77

G 0.54

E 0.37

M 0.36

B 0.33

D 0.32

A 0.28

N 0.23

L 0.19

K 0.15

H 0.11

J 0.07

P 0.03

fast group

intermediate group

Mean $\tilde{x}=0.38$

Standard error $s=0.52$

$\bar{x}-0.5 s=0.25$

$\bar{x}+1 s=1.03$

$\bar{x}-0.5 s=0.225$

$\bar{x}+1 s=0.69$

Rank correlation, 1979 and period 21980 (without D)

$\begin{array}{lcccccc} & \text { I } & \text { E } & \text { G } & \text { N } & \text { H } & \text { K } \\ 1979 & 1 & 2 & 3 & 4 & 5 & 6 \\ \text { period 2 1980 } & 1 & 2.5 & 2.5 & 4 & 6 & 5\end{array}$

Rank correlation coefficient $=0.93$ (significant at $5 \%$ )

Rank correlation, periods 2 and 3, 1980

period 21980

period 31980

$\begin{array}{cccccccccc}\text { I } & \text { D } & \text { E } & \text { G } & \text { M } & \text { N } & \text { K } & \text { L } & \text { J } & \text { H } \\ 1 & 2 & 3.5 & 3.5 & 5 & 6 & 7 & 8 & 9.5 & 9.5 \\ 1 & 5 & 3 & 2 & 4 & 6 & 8 & 7 & 10 & 9\end{array}$

Rank correlation coefficient $=0.91$ (significant at $0.1 \%$ )

Recording the appearance of dye from points with very long transit times (delays) was difficult, and on two occasions no dye was recorded at all in either outflow stream during the recording. However, the time/concentration curve recorded from moulin $\mathrm{H}$ on 18 September 1980 shows a pattern typical of those obtained when recording was continued for a long period (Fig. 5).

\section{Diurnal variations of velocity}

During periods 2 and 3 in 1980, three major moulins were used for repeated dye tests in a single day, to investigate variations of throughflow velocity. The results (Fig. 6) showed that the variations were remarkably similar for all moulins, and that peak velocity was up to ten times the velocity recorded in the early morning. During period 2, maximum velocities occurred between 15.00 and $16.00 \mathrm{~h}$, whereas the peak appeared to occur slightly earlier during period 3 , at about 


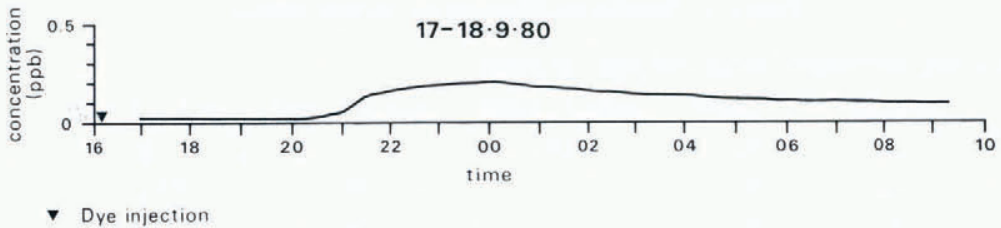

Fig. 5. Time/concentration curve from moulin $H$.

$14.00 \mathrm{~h}$. Continuous records of the outflow stream discharge between 6 August and 8 September 1980 indicated that peak daily discharge occurred at around $15.30 \mathrm{~h}$, with no marked tendency to become earlier through the period, although the time of minimum discharge changed from about 7.15 to $9.15 \mathrm{~h}$, probably in association with the later sunrise. Maximum inputs to the system are likely to occur at about $12.50 \mathrm{~h}$, the time of maximum radiation input to the glacier surface (Burkimsher, unpublished). There is clearly a very close relationship between changes in discharge and travel times through the system during the day.

\section{Seasonal variations of velocity}

Repeated tracer tests from six moulins in different periods allowed seasonal comparisons to be made. Throughflow velocities (Table V), corrected to peak daily velocity using the patterns summarized on Figure 6, were highest in mid-summer (period 2); the ratios of each travel time in a particular period to that in this "base period" were remarkably similar for different moulins. The only anomalous result was that from a test carried out at point I in 1979, three weeks before the other 1979 tests; the glacier river discharge probably changed considerably in the intervening period.

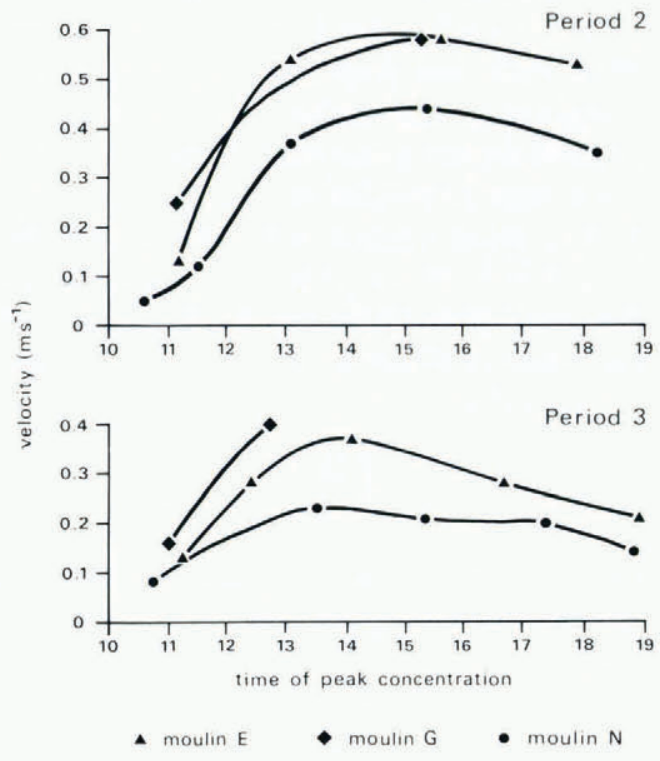

Fig. 6. Diurnal variations of throughflow velocities. 
TABle V. Seasonal Changes In TRAVEl times

Travel times (in minutes) corrected to estimated peak velocities

$\begin{array}{ccccc}\text { Moulin } & 1979 & \text { period 1 1980 } & \text { period 2 1980 } & \text { period 3 } 1980 \\ \text { N } & 29 \pm 2 & 57 & 21 & 40 \\ \text { G } & 52 \pm 2 & 165 \pm 5 & 42 & 52 \pm 5 \\ \text { E } & 43 \pm 2 & \cdot & 42 & 65 \\ \text { M } & \cdot & . & 23 \pm 2 & 44 \pm 5 \\ \text { I } & 23 \pm 2 & 30 \pm 2 & 10 \pm 3 & 19 \pm 3 \\ \text { D } & \cdot & . & 42 \pm 5 & 85 \pm 10\end{array}$

Travel times expressed as factors of period 21980 travel times (=time delay ratios).

\begin{tabular}{|c|c|c|c|c|}
\hline Moulin & 1979 & period 11980 & period 21980 & period 31980 \\
\hline $\mathrm{N}$ & $1.2-1.4$ & 2.7 & 1.0 & 1.9 \\
\hline G & $3.2-1.3$ & $3.8-4.0$ & 1.0 & $1.1-1.4$ \\
\hline E & $0.9-1.1$ & . & 1.0 & 1.5 \\
\hline M & . & . & 1.0 & $1.6-2.3$ \\
\hline I & $1.6-3.6$ & $2.2-4.6$ & 1.0 & $1.2-3.0$ \\
\hline G & . & . & 1.0 & $1.6-2.6$ \\
\hline Mean travel-time ratios $t_{\mathrm{x}} / t_{2}$ & $\begin{array}{c}1.2 \\
\text { (not inc. I) }\end{array}$ & 3.3 & 1.0 & 1.8 \\
\hline Average peak discharge $Q_{x}\left(\mathrm{~m}^{3} / \mathrm{s}\right)$ & . & 1.5 & 13.7 & 4.8 \\
\hline$\sqrt{Q_{2} / Q_{x}}$ & . & 3.0 & 1.0 & 1.7 \\
\hline
\end{tabular}

No discharge data were available for 1979, and continuous records of discharge were available for only two days on which dye tests were carried out in 1980. Values of average peak daily discharge for the three study periods in 1980 were estimated from the total daily discharge, recorded by Tauernkraftwerke AG, and from dye dilution data obtained from complete time/concentration curves (Burkimsher, unpublished). It was considered reasonable to use one value of peak discharge for each field period because the periods were only short and the base flow component, which forms a high proportion of total discharge, changes only slowly. Most tracer tests were done on days of good weather, when the diurnal discharge pattern would be similar. Variations of both glacier river discharge and the calculated travel-time ratios (Table V) were much smaller within each study period than between periods. From the data, a relationship was established between travel times in different periods and discharge in those periods. A good fit for all the data is given by the equation:

$$
\frac{t_{1}}{t_{2}}=\left(\frac{Q_{2}}{Q_{1}}\right)^{1 / 2}
$$

where $t$ is the travel time and $Q$ the discharge and the subscripts 1 and 2 relate to any two periods. Expressed in terms of velocity $v$, this gives:

$$
\frac{v_{1}}{v_{2}}=\left(\frac{Q_{1}}{Q_{2}}\right)^{1 / 2} \text {. }
$$

There is, therefore, a marked difference between the diurnal and seasonal velocity variations. 
In the diurnal case, changes in total discharge are comparatively small, but velocities may change by an order of magnitude. In contrast, seasonal variations of total daily discharge are large, but have only a relatively small effect upon velocities.

\section{Discussion}

The results of the Pasterzengletscher dye tracer tests have implications with regard to both the form of the internal hydrological network and water flow through it. Close interrelationships between water flow through channels and channel evolution are also revealed.

\section{Internal hydrological network}

Throughflow velocities from most of the moulins tested on Pasterzengletscher fell into the "average" band of 0.2 to $1.5 \mathrm{~m} \mathrm{~s}^{-1}$ reported from other glaciers. The similarity of these velocities to those in supraglacial streams led Behrens and others (1975) to conclude that water passed from moulins to snout in large channels which had open-channel flow. Although the occurrence of open-channel flow may be questioned, the lack of significant delays from most moulins does indicate that flow is in discrete conduits, and not as seepage through intergranular veins or a subglacial water film. However, the channel network on the Pasterzengletscher cannot be very dense or well integrated as some moulins appear not to be connected to the fast throughflow system. This irregular pattern is in contrast to the situation at Storglaciären and Mikkaglaciären where there were systematically longer time delays from moulins further away from the glacier snout (Stenborg, 1969). Remarkably slow passage of water from some points on the ablation area has been recorded elsewhere (Krimmel, 1978) and it has been suggested that some water passes into "temporary storage" when negative results have been obtained (Theakstone and Knudsen, 1981). The results from the "slow" group of moulins on the Pasterzengletscher (Table IV) showed that long delays were permanent features of particular routeways. The cause of the long delays is difficult to establish. Throughflow velocities were not correlated to moulin size. Other possible explanations include passage of water through a considerable layer of ground moraine (of the sort described by Engelhardt and others, 1979) or through one large or several small sub- or englacial bodies of water. Evidence of large reservoirs in Vatnajökull has been presented by Gudmundsson and Sigbjarnarson (1972), and general water flow through series of subglacial cavities has been proposed by Lliboutry (1968).

Water entering moulins eventually appears at a major outflow stream from the glacier snout. At Pasterzengletscher, as at many other glaciers, there are two outflow streams, and it is reasonable to suppose that these trunk streams extend at least some distance up-glacier. As demonstrated above, the left trunk stream at the Pasterzengletscher appears to be close to the glacier margin and to extend at least $4 \mathrm{~km}$ up-glacier from the snout. Water velocity in this stream, reaching nearly $2 \mathrm{~m} \mathrm{~s}^{-1}$ at times of peak velocity, is much higher than that in other routeways.

It is more difficult to deduce the position of the right trunk stream. The configuration revealed by retreat of the snout suggested that its lowest reach, at least, lay below the morainecovered ice. Further up-glacier, it is likely that the water from moulins D, E, G, M, and N flows only a short distance before reaching the trunk stream, as it is these from which throughflow velocities to the right outflow stream were highest. Seismic depth measurements of the central part of the glacier tongue (Brockamp and Mothes, 1931) indicate that the deepest point of the 
valley follows approximately this line, and it is likely that the right trunk stream follows the talweg. However, an overdeepened basin in the vicinity of moulins D and G, with an absolute altitude approximately the same as the glacier snout may discourage the presence of a large subglacial stream.

On Pasterzengletscher many moulins on left-trending crevasses feed the right outflow stream, which contradicts Stenborg's (1969) explanation of a drainage division. Röthlisberger (1972) proposed, on theoretical grounds, that the main trunk streams of a glacier may lie in lateral subglacial positions at the "hydraulic grade line", with the possibility of a third stream at the deepest part of the valley. Pasterzengletscher may follow this model, with the exception that no grade-line stream lies near the right margin.

Another theoretical model has been proposed whereby the internal channel network is fully arborescent, with small channels leading successively to larger ones and ultimately to one trunk stream (Shreve, 1972). The results from Pasterzengletscher indicate that, although in most cases channels do, indeed, lead into successively larger ones, there are two weaknesses in the model. The first is that it does not accommodate a major lateral division of the drainage network; the second that water may not pass into two or more channels from a single moulin. At Pasterzengletscher, water from a moulin may pass into one route which ultimately leads to the left outflow stream and into another route leading to the right one. Elsewhere, water may pass into two routes which have different delay factors, but which rejoin the same trunk stream, causing a multiple peak on the time/concentration curve. Tests from moulin $\mathrm{N}$ indicate that the seçondary route may be an overflow used when the main channel is filled to capacity at times of high discharge. Possibly, therefore, most of the water entering moulins which lie on left-trending crevasses passes into channels which rapidly lead to the ice/bedrock interface and thence down-slope towards the right trunk stream at the talweg, but some water overflows along the crevasse bases and so towards the left margin, to enter the left trunk stream.

\section{Water flow through the network}

Röthlisberger (1972) suggested that englacial channel size approaches an equilibrium value as growth by melting and shrinkage caused by overburden pressure are balanced. Channels, therefore, shrink in winter and expand to accommodate maximum discharge in summer. Maximum discharge from Pasterzengletscher in 1980 probably occurred during period 2 when repeated tests were carried out from a single moulin. Throughflow velocities then were extremely high, but there were no indications of "blockages" occurring. Pressure flow in completely waterfilled conduits must have been prevalent in the system at this time. Although velocities in such conditions may be equivalent to those in open channels (Behrens and others, 1975), there is no possibility of open-channel flow being common in most parts of the system at this time. Indeed, when open-channel flow was likely to be most widespread, at times of minimum discharge, throughflow velocities were considerably lower. The magnitude of daily variations in throughflow velocities - by up to an order of magnitude-probably reflects pressure flow conditions, in which the driving force is the pressure gradient; such velocities are much greater than those under open-channel flow, when, other factors being equal, the gradient of the channel is the driving force. In sewers, the transition from open-channel flow to pressure flow may be violent (Mussalli, 1978). Thus, large diurnal variations of velocity could be caused by changes in the proportion of completely water-filled channel lengths. Major variations in the water level in moulins, possibly related to such changes, have been observed on other glaciers (Iken, 1972). 
On a daily basis, channel sizes cannot adapt to cope with the rapidly changing discharge passing through them. However, on a seasonal basis, they can, although the speed of adaptation is not known precisely (Röthlisberger, 1972). Röthlisberger proposed that the water level in a glacier may become higher in winter, when water flow is very low. In this case, the lower the average discharge through the glacier, the higher would be the proportion of completely waterfilled channel. Changes in throughflow velocities between summer and winter predicted by Röthlisberger (1972) were even smaller, for larger changes in discharge, than the empirical results obtained at Pasterzengletscher. The relationship between seasonal variations of velocities and discharge at Pasterzengletscher indicates that internal channels must change in size to cater for the change of average discharge passing through them. The proportion of the length of channel which has pressure flow, therefore, remains roughly constant. The results from the Pasterzengletscher hydrological experiments suggest that the channels adapt quite quickly over a period of weeks to changes in average discharge through them.

\section{ConClusions}

The results of dye tracer tests at Pasterzengletscher have important implications regarding the internal channel network of many temperate glaciers. The network configuration is characterized by a major lateral division and bifurcations on many routeways, and this general pattern is much more complex than that implied from some tracer tests reported on other glaciers. Evidence that the size of channels adapts to cope with varying discharge was found, although it is unlikely that most channels can adapt within the daily cycle. Further empirical tests are needed to ascertain whether such conclusions have general applicability. Both theoretical and practical exploration is needed to determine the proportion of channel routeways which are completely water-filled, and the influence on glacial hydrology of the change from open-channel flow to closed pressure flow within internal conduits. Although the gathering of a usefully comprehensive data set is time-consuming, the results obtained at Pasterzengletscher amply demonstrate the value of dye tracer techniques. More theoretical modelling is required to explain some of the empirical results.

\section{ACKNOWLEDGEMENTS}

The writer was a research student funded by the United Kingdom Natural Environment Research Council. Financial help for other field assistants was given by Tauernkraftwerke AG, Austria, and the New York Explorers Club. I should like to thank Wilfred H. Theakstone, my supervisor, for all his assistance, staff at Graz, Salzburg, and Innsbruck Universities for their advice, and the many people who gave uncomplaining labor in the field work.

\section{MS. received 12 November 1982 and in revised form 18 January 1983}

\section{REFERENCES}

Ambach, W., and Eisner, H., [1981.] Ein Tracerexperiment zum Schmelzwasserfluss in der Wassertafel eines tempierten Gletschers. Zeitschrift für Gletscherkunde und Glazialgeologie, Bd. 15, Ht. 2, 1979, p. $229-34$. 
Behrens, H., and others 1975. On the water channels of the internal drainage system of the Hintereisferner, Otztal Alps, Austria, by H. Behrens, H. Bergmann, H. Moser, W. Ambach, and O. Jochum. Journal of Glaciology, Vol. 14 , No. 72 , p. $375-82$.

Brockamp, B., and Mothes, H. 1931. Seismische Untersuchungen auf dem Pasterzengletscher, I. Zeitschrift für Geophysik, Bd. 6, Ht. 8, p. 482-500.

Burkimsher, M. Unpublished. The internal drainage of an alpine glacier. [Ph.D. thesis, University of Manchester, 1982.]

Collins, D. N. 1982. Flow-routing of meltwater in an alpine glacier as indicated by dye tracer tests. Beiträge zur Geologie der Schweiz. Hydrogeologie, Bd. 28, Ht. 2, p. 523-34.

Engelhardt, H., and others. 1979. Observation of basal sliding of Variegated Glacier, Alaska, by H. Engelhardt, W. B. Kamb, C. F. Raymond, and W. D. Harrison. Journal of Glaciology, Vol. 23, No. 89, p. 406-07.

Gudmundsson, G., and Sigbjarnarson, G. 1972. Analysis of glacier run-off and meteorological observations. Journal of Glaciology, Vol. 11, No. 63, p. 303-18

Iken, A. 1972. Measurements of water pressure in moulins as part of a movement study of the White Glacier, Axel Heiberg Island, Northwest Territories, Canada. Journal of Glaciology, Vol. 11, No.61, p. 53-58.

Krimmel, R. M. 1978. Subglacial dye injection test. U.S. Geological Survey. Professional Paper 1100, p. 213.

Krimmel, R. M., and others. 1973. Water flow through a temperate glacier, [by] R. M. Krimmel, W. V. Tangborn, and M. F. Meier. (In [International Hydrological Decade.] The role of snow and ice in hydrology. Proceedings of the Banff symposia, September 1972. Paris, UNESCO; Geneva, WMO; Budapest, IAHS, p. 401-16. (Publication No. 107 de l'Association Internationale d'Hydrologie Scientifique.))

Lang, H., and others. [1981.] Results from tracer experiments on the water flow through the Aletschgletscher, by H. Lang, C. Leibundgut, and E. Festel. Zeitschrift für Gletscherkunde und Glazialgeologie, Bd. 15, Ht. 2, 1979, p. 209-18.

Lliboutry, L. A. 1968. General theory of subglacial cavitation and sliding of temperate glaciers. Journal of Glaciology, Vol. 7, No. 49, p. 21-58.

Mussalli, Y. G. 1978. Size determination of partly full conduits. Journal of the Hydraulics Division, Proceedings of the American Society of Civil Engineers, Vol. 107, HY7, p. 959-74.

Ramspacher, P. Unpublished. Am inneren Abflussystem im Ablationsgebiet des Pasterzengletschers (Glocknergruppe). [Internal paper of Institut für Geothermie und Hydrogeologie am Forschungszentrum Graz, Austria.]

Röthlisberger, H. 1972. Water pressure in intra- and subglacial channels. Journal of Glaciology, Vol. 11, No. 62, p. 177-203.

Shreve, R. L. 1972. Movement of water in glaciers. Journal of Glaciology, Vol. 11, No. 62, p. $205-14$.

Stenborg, T. 1969. Studies of the internal drainage of glaciers. Geografiska Annaler, Vol. 51 A, Nos. 1-2, p. 13-41.

Theakstone, W. H., and Knudsen, N. T. 1981. Dye tracer tests of water movement at the glacier Austre Okstindbreen, Norway. Norsk Geografisk Tidsskrift, Vol. 35, No. 1, p. 21-28.

Turner Designs. 1976, Fluorometric facts: flow measurements. Mountain View, California, Turner Designs. (Monograph FR9-76.) 